Article

\title{
Payback, Forgiveness, Accountability: Exercising Responsible Agency in the Midst of Structured Racial Harm
}

\author{
Michael P. Jaycox
}

Theology and Religious Studies Department, Seattle University, Seattle, WA 98122, USA; jaycoxm@seattleu.edu

Received: 22 August 2019; Accepted: 10 September 2019; Published: 13 September 2019

\begin{abstract}
In a context of political conflict, the practice of vengeance, the paying back of harm in exchange for harm suffered, is obviously an ethical problem. The practice of forgiveness is equally though differently problematic when applied to political conflict despite the fact that it is a moral ideal. A third approach, the practice of moral accountability, is more ethically justifiable, yet it remains unclear what it is conceptually and what it would involve practically in a particular context. In this essay, the author develops a conceptual framework for moral accountability, grounded in a broader understanding of justice as responsibility to conflictual and unchosen relationships. Drawing on contemporary sources in Christian ethics, as well as insights from anti-racism community organizing, the author argues that practices of moral accountability restructure the pattern of these relationships, such that perpetrators and guilty bystanders are more likely to assume, rather than avoid, responsibility for causing structured racial harm.
\end{abstract}

Keywords: accountability; responsibility; justice; ethics; vengeance; forgiveness; agency; racism; community organizing; Christianity

Let us consider the words of the South African director and writer Jann Turner, who relates her experiences of the anti-apartheid movement and the death of her own father in the context of the Truth and Reconciliation Commission (TRC):

A healthy normal reaction ... is that ... I mean, that you should want to go and just hit them, hurt them, get revenge. I mean, I don't have that reaction, and I know a lot of women don't. I've talked to Jillian Slovo, whose mother was killed ... by parcel bomb, Ruth First. Jillian and I talk quite a lot, and we've talked about why don't we have that reaction. Why is it that we just want to face that person and say, 'Can you explain to me why you did that?' Why don't we want to do what Mario Scurn wants to do about the killers of his wife, is face that person once and only once, and that's through the sights of an AK47? Which is really kind of healthy, in a weird way. I don't know what it is, but it seems more normal than wanting to sit down and face them in this extraordinary Kafkaesque Truth Commission, where we sit and listen and go in the breaks and have cups of tea.

\section{(Hoffmann and Reid 2000)}

If we are to ask what is owed in justice to victims and survivors of grave social harm, then we must also address the difficult issue of who owes the debt. How are we to assign responsibility for harm to specific agents? Turner is considering the responsibility to be assigned to perpetrators, but the broader context of South African society under the apartheid system redirects our attention to the more difficult task of assigning responsibility to the complicit beneficiaries of the unjust social structures that compound and inequitably distribute social harm (Traina 2014, p. 174). This line of questioning leads us to consider the social conditions that prevent, and those that facilitate, the assuming of responsibility 
by the beneficiaries of institutionally structured violence, given the strong tendency of such agents to avoid assuming the responsibility accurately assigned to them (Schweiker 1995, pp. 136-37, 189-91; Traina 2014, pp. 187-88). Agents who are positioned as guilty bystanders and beneficiaries of a pattern of harmful structural relationships frequently exhibit habits of privileged helplessness, denial, and self-deception, which propel the reluctance to assume responsibility for the harm they indirectly cause (Vasko 2015, pp. 15-18; Applebaum 2010, pp. 140-43).

In keeping with the theme of this special issue of Religions, I wish to address these problems through the juxtaposition of payback and forgiveness with accountability as three broad categories of ethical practice used to negotiate the assigning of responsibility for harm to direct perpetrators and indirect beneficiaries, and their voluntary assuming of this responsibility, in relation to victims and survivors. Much of the discussion of these issues has been guided by ethical theories of responsibility, both theological and philosophical (Niebuhr 1999; Schweiker 1995; Young 2013). However, these issues are also addressed in the applied ethical field of transitional justice, in which scholars study the social conditions that enable the members of formerly authoritarian societies to reckon with the impact of past human rights violations as they begin to establish democratic norms of governance (Minow 1998; Shriver 1997; Tutu 2000; De Gruchy 2002; O’Neill 2002). Those who are officially charged with this task typically must decide whether the judiciary will hold human rights violators to account by punishing them, so as to acknowledge the injustice done to victims and survivors and deter the commission of such crimes in the future. Alternatively, they may elect to offer human rights violators opportunities for legal amnesty in the interest of obtaining evidence, promoting social reconciliation, or simply for reasons of political expediency.

However, both options available in this apparently binary choice faced by post-conflict societies-payback via prosecution, or forgiveness via amnesty-are highly limited as means of reconstructing a moral culture. Neither option really gets to the depth of Turner's deceptively simple question for her father's killer: "Can you explain to me why you did that?" Her question does not seek factual information but rather an accounting from a moral subject, an explanation of how they rationalized the misuse of their agency. Yet even Turner's question, addressed to a direct perpetrator, does not really face the moral banality evident in a society full of agents who passively observe and benefit from structural harm. In such a society, who specifically should be assigned responsibility for the harm done to whom? If guilty bystanders assume this responsibility, what account should they give of themselves to victims and survivors? How, exactly, did they rationalize their inaction? The relevance of these broader questions of moral accountability reaches beyond the context of post-conflict societies, such as South Africa, extending to societies that are drifting toward a more authoritarian pattern of rule, such as the United States at the time of this writing. For instance, which agents should be held responsible for the sexual abuse, lack of sanitation and health care, traumatization, and preventable death that the emerging system of concentration camps along the U.S.-Mexico border inflicts on children and adults? It is tempting to limit responsibility for these harms to perpetrators and their superiors, but the responsibility of guilty bystanders cannot be ignored.

The focus of this essay will be an examination of moral accountability practices in the interest of developing an adequate theoretical understanding of this ethical category. Practices of moral accountability are indispensable for the exercise of responsible agency in the context of the conflictual and unchosen structural relationships that have come to define life in contemporary human societies. Unlike the practices of payback and forgiveness, practices of moral accountability can restructure relationships on a new pattern that facilitates the voluntary assumption of responsibility by the agents to whom responsibility is most accurately assigned. But this assumption of responsibility has a cost in that it necessarily involves a disturbing transformation of the responsible agent's self-perception, having recognized they are capable of incurring guilt not only for past harms but also for likely future harms in the context of ongoing, unchosen, conflictual relationships. Since the voluntary assuming of responsibility includes this non-coercive, extralegal form of punishment, moral accountability may not be that distant from its more straightforward cousin: payback. However, unlike payback, this peculiar 
type of punishment involved in moral accountability is not without mercy, because the goals of the practice are to heal and restore harmed relationships and to transform institutional structures in order to prevent further harm.

In order to unpack this argument, first I will distinguish moral accountability from payback and forgiveness using the discussion of these concepts in the field of transitional justice as a guide. Second, building on the work of Tisha Rajendra (2017), I will elaborate a conceptual framework for moral accountability as a practice that expresses justice as responsibility to unchosen, conflictual relationships. In this section, I will treat racial injustice in the United States as the particular context in reference to which theoretical questions are considered. Third, I will examine the connections and overlap between moral accountability and related concepts in Christian ethics, such as reconciliation, reparation, cooperation, and complicity. Fourth and finally, I will revisit the distinction between accountability and payback in light of the question of whether accountability includes a punitive element for perpetrators and guilty bystanders.

\section{Moral Accountability in Contrast to Payback and Forgiveness}

In the transitional justice literature, one can generally find broad acknowledgement of the moral compromises involved in all of the existing, viable strategies available to post-conflict societies, including truth commissions, conditional amnesty for perpetrators, criminal prosecution for perpetrators, structural reforms, and monetary reparations for victims and survivors. Some scholars have noted, for instance, that the South African TRC blurred the lines between its moral, political, therapeutic, and religious goals and failed to deliver on many of them (Wilson 2001, pp. 19-20), while others have noted that the TRC did not hold the system of apartheid itself, or its beneficiaries, accountable for racial harm (Chapman 2008, p. 88). Finding truth commissions and other post-conflict strategies limited as means to the end of reconstructing a culture of moral accountability, Martha Minow asks: "What responses do or could lie between vengeance and forgiveness, if legal and cultural institutions offered other avenues for individuals and nations?" (Minow 1998, p. 21).

Martha Nussbaum (2016) has argued that the practice of vengeance, regardless of its social effects, is already wrong in itself because it is based on the evidently false belief that the suffering of a perpetrator can and will compensate for the suffering of the victim or survivor; thus, she terms this false belief "payback." The desire to pay back suffering is not necessarily intended in every act of punishment, since punishment can also be imposed with the intention to protect the innocent and to reform the perpetrator. Rather, "payback" is a specific type of punishment in which "getting even," creating some balance of suffering, is the intended purpose. Minow is concerned that this vengeance can and often does exceed the limits prescribed by the lex talionis, leading to the possibility of cyclic social violence, especially when carried out by private individuals rather than the state. She also notes, however, that the desire for vengeance gestures toward something appropriate and fundamental to the concept of justice, namely the sense that punishments should be imposed in proportion to crimes (Minow 1998, pp. 10-14). Desmond Tutu argues that this desire for vengeance, while understandable as an attempt to affirm the dignity of victims and survivors, does not promote social reconciliation, not to mention the fact that the prosecution of perpetrators is often practically impossible and prohibitively expensive in the context of a post-conflict society (Tutu 2000, pp. 19-23). Moreover, the desire to punish perpetrators often stands in practical competition with the goal of obtaining an accurate record of past events, since perpetrators, who are often the only living witnesses to their deeds, have little incentive to disclose the truth if they are facing prosecution (Minow 1998, p. 59; Tutu 2000, pp. 23-24, 58).

Forgiveness, on the other hand, is typically held to be a moral ideal in both secular culture and religious cultures, and its political applications are highly significant, as Tutu's work in the South African context ably demonstrates. Shriver (1997) also argues favorably for a political application of forgiveness precisely because of the limitations of an approach to political justice based on mere retribution. However, one inevitable aspect of forgiveness, namely the relinquishing of certain means by which to advance claims for redress, carries enormously troublesome implications for societies 
in which the inequitable distribution of power is cemented in an oppressive system (Shriver 1997, pp. 7-8, 30-31). For instance, Shriver calls attention to the extraordinary willingness of black Americans to forgive white Americans for slavery, segregation, lynching, police brutality, economic deprivation, and other forms of structured white supremacist violence, and he even argues that the lack of reciprocal acknowledgement of responsibility from white Americans implies that black Americans "are right to withhold some measure of that forgiveness until they are dealt a fuller measure of just reparation by this society" (Shriver 1997, pp. 225, 173, 216). However, he does not seriously face the implications of the fact that a completed process of forgiveness, which includes reciprocity by his own definition, is an activity in which members of oppressor groups are unreliable participators simply because they possess the power to opt out without consequences (Shriver 1997, pp. 7, 210).

As a note of further skepticism, Minow raises the concern that using forgiveness as a political tool in post-conflict societies "institutionalizes forgetfulness, and sacrifices justice in a foreshortened effort to move on" (Minow 1998, p. 15). Furthermore, forgiveness "seems to rule out retribution, moral reproach, nonreconciliation, a demand for restitution, and, in short, any act of holding the wrongdoer to account" (Minow 1998, p. 16; Calhoun 1992, pp. 76, 84). Indeed, individual victims and survivors may practice forgiveness voluntarily for therapeutic reasons so that they might be able to function after an experience of trauma. However, this salutary practice can in no way be treated as morally equivalent to the state's offer of amnesty to perpetrators, whatever conditions it may include or however carefully it is implemented. For "amnesty is lawful amnesia; and what takes place at this highly formalized level may also take place in the domain of the social or collective memory." (Minow 1998, p. 20; Hartman 1994, pp. 1, 14). Indeed, some scholars have more recently argued that forgiveness is not reducible to pure relinquishment of claims for redress, which suggests that political applications of forgiveness not only can promote social reconciliation but also can coexist with the legal and morally just punishment of perpetrators (Philpott 2012, pp. 251-85). However, it remains possible that the political application of forgiveness can produce an unjust peace and even enable those who abuse power, thereby thwarting attempts to reconstruct a culture of moral accountability.

But what if the goal is not to reconstruct this culture but to preserve it when it is under threat? While it has become obvious that both vengeance and forgiveness are highly limited as means to reconstructing this culture in post-conflict societies, we have fewer mileposts for knowing how to preserve and practice moral accountability in societies moving in the direction of authoritarianism. Even in Minow's work on post-conflict societies, the term "accountability" seems to refer to a generalized political ideal, advanced primarily by the legal means of prosecution through judicial processes (Minow 1998, pp. 9, 16, 48, 57, 87-88). Tutu employs the term to refer to a moral ideal in which perpetrators voluntarily assume responsibility for harm, but he understands the reconstruction of this ideal in the South African context to be dependent on the conditional amnesty procedure of the Truth and Reconciliation Commission and on the distinctive cultural worldview of ubuntu (Tutu 2000, pp. 30-31, 50-55). How is moral accountability to be practiced and understood in the context of increasingly authoritarian societies such as the United States, which lack the benefit of moral hindsight possessed by many post-conflict societies? Is moral accountability possible if responsible agents are acting — or failing to act—with impunity because the pattern of structural harm is, in fact, entirely legal?

\section{Moral Accountability in Practice and in Theory}

Any deductive attempt to answer these questions by proposing an abstract definition of accountability as a moral ideal would be misguided. Rather, I argue that the term moral accountability refers to the particular practices that are appropriate to a specific relational context of injustice because they function to restructure relationships toward justice in that context. Since many, though not all, of those reading this essay are likely to be educators who live and work in the U.S. context of unjust interracial relationships, it is well worth asking to whom educators are accountable and what practices of accountability would be appropriate to these relationships. Theological and religious educators 
in particular arguably are accountable not only to the academy but also to religious congregations and social movements in the societies to which they belong (Tracy 1991, pp. 3-31). The persistent challenge, however, particularly for white educators who wish to practice accountability in interracial and intraracial relationships, is to avoid using their involvement as a means for advancing their own individual interests or addressing their own psychological needs. In this regard, AnneMarie Mingo calls attention to "collective work and responsibility" as a historically effective ethical strategy for racial justice organizing in the U.S. context (Mingo 2018, p. 702). Participants in the Civil Rights Movement, for example, "were not generally doing so principally for personal gain, since their efforts to force changes in laws and practices were often at great personal risk; they prioritized communal progress over individual advancement" (Mingo 2018, pp. 702-3). A question for the purposes of this investigation, therefore, is how to practice moral accountability in interracial and intraracial relationships such that the goals of the anti-racism collective will be prioritized over the needs and desires of individual educators who participate, particularly white educators.

In my local context of Seattle, for example, educators practice interracial accountability through their participation in several racially differentiated anti-racism collectives. Persons of color (POC) who have been doing anti-racism organizing work, particularly in regard to racially-biased policing, youth incarceration, and ICE detention of undocumented persons, often belong to organizations such as End the Prison Industrial Complex (EPIC), Youth Undoing Institutional Racism (YUIR), Village of Hope, and Black Prisoners Caucus, while white persons collaborating as allies in this same organizing work (myself included) often belong to the organization European Dissent (ED). Members of the leadership of local POC organizations will often observe ED meetings and offer feedback and follow-up questions. Often members of EPIC or YUIR will make a specific "ask" to ED members to be present at a planned public event and to act in a specific role. For instance, members of ED might be asked to place their bodies in between the Seattle police and the members of EPIC and YUIR, knowing that white persons are less likely to be arrested than POC and usually have more resources to cope with this kind of event. In other contexts, members of ED might be asked to be present in the background, while public-facing roles are occupied by members of POC organizations so that those most adversely affected by racial injustices have greater visibility to non-participants. Additionally, most of these groups have historical and ongoing relationships with a national anti-racism organization, The People's Institute for Survival and Beyond, which includes maintaining accountability to communities among its central anti-racist principles. The cumulative effect of participation in these particular moral accountability practices at the grassroots level is the gradual restructuring of responsibilities in interracial and intraracial relationships, in disruption of the unaccountable pattern of relationships structured by the dominant political and economic institutions of U.S. society.

In regard to relationships with students, my colleagues and I who teach courses on race and racism create a system of moral accountability in the classroom by employing, when appropriate, a "racial identity caucusing" pedagogy adapted from anti-racism community organizing (Crossroads Antiracism Organizing \& Training 2008). In the classroom, even self-identified liberal white students frequently derail discussions of racial injustice by performing certain learned behaviors that reflect an unconscious assumption of racial superiority. On the one hand, they know that if they are to protect their reputation, they must display their awareness of white privilege and speak in such a way that hints toward their righteous outrage and socially transgressive identity. Yet, on the other hand, these same liberal white students are often quite resistant to their views and assumptions being questioned and challenged (Scheid and Vasko 2014; Nishi et al. 2016). Their persistent refrain, "what can white people do?", is a particularly troublesome question, especially when directed toward students and professors of color, since it removes the white speaker from the critique of whiteness and re-centers attention on the agency of white people (Ahmed 2007, pp. 164-65; Applebaum 2010, pp. 5-6). The practice of racial identity caucusing addresses this and other pedagogical problems by restructuring the pattern of student relationships. Since the composition of small groups discussing the readings is determined on the basis of racial identity, each group has an opportunity to focus on their 
particular needs and concerns and to prepare to report back to one another afterward. In the reporting back, groups composed of white students are accountable to the groups composed of students of color to narrate the intellectual and political work they have done and plan to do, and they then respond to feedback and follow-up questions. In addition, my colleagues and I who use this pedagogy maintain accountability to one another by participating in faculty groups focused on sharing strategies that help us to implement racial justice in the classroom.

The accountability practices that restructure interracial relationships also imply a need for corresponding practices that restructure intraracial relationships, particularly among white people. In order to demonstrate their accountability, white allies to persons of color "must employ the dispositions and practices of counter-framing to dissent from or disrupt practices of white supremacy in frontstages and backstages of white life, particularly when whiteness is performed by people in kinship, friendship, and professional networks" (O'Connell 2014, p. 102; Picca and Feagin 2007; Feagin 2010, pp. 155-91). Counter-framing may involve, for example, asking others to explain what is meant when coded racial language is being used, proposing anti-racist alternative interpretations of encounters and events, or simply narrating a personal experience of realizing one's own socialization into white supremacist frames of perception. Such practices necessarily involve risk, since the act of disrupting the continuous normalization of white supremacy in the context of white networks can result in the loss of valued relationships, as well as the financial support, emotional support, and social capital that derive from participation in such networks. However, if white supremacist behaviors in exclusively white networks remain undisrupted, then white people will remain unable to exercise responsible agency in their intraracial and interracial relationships, leaving patterns of structured racial harm unquestioned and unchecked by its primary beneficiaries.

Note that the intended purpose behind my enumeration of interracial and intraracial moral accountability practices in this forum is not merely exhortative, i.e., to encourage readers into virtuous imitation in order to restructure relationships. I also mention them because being able to understand the relational context of specific accountability practices must be central to the task of elaborating any credible ethical theory of moral accountability. Especially in a society drifting toward a more authoritarian pattern of using institutional power, our work of educating and organizing in the chosen and unchosen relationships in which we find ourselves, and our critical efforts to theorize about this work, become all the more urgent in order to model responsibility and to protect and transmit a moral culture of responsibility.

Tisha Rajendra (2017) also utilizes this inductive methodological attentiveness to particularity as the basis of her theory of responsibility to relationships. Focusing on relationships between citizens and migrants, she argues that "there is no neat formula for determining what responsibilities follow from what kinds of relationships. Instead, responsibilities are allocated through social narratives that run beneath the surface of our ideas about justice for migrants" (Rajendra 2017, p. 7). For example, she invites us to consider the case of Mario Alapizco Castro, an undocumented migrant from Guatemala whom the U.S. government deported to Mexico. For all practical purposes, he has become stateless, since his congenital heart defect and lack of money prevent his being able to travel back to Guatemala or to attempt to enter the U.S. again. Most ethicists would affirm that Castro has a right to heart surgery, but his status as a migrant, who is effectively ineligible for the health care benefits that accrue to citizens of Mexico or the U.S., makes it difficult to identify the specific parties who owe him health care, i.e., those to whom responsibility is to be assigned for fulfilling his right (Rajendra 2017, pp. 11-12).

Some ethicists suggest that bystanders with available resources are responsible for entering into relationship with vulnerable strangers like Castro and helping them when no one else can or will, because moral duties to such persons transcend or even override the civil laws of sovereign nations (Gutiérrez 2008; Hollenbach 2008; O'Neill 2009). However, Rajendra argues that the use of this language of "bystander" and "stranger" often presupposes certain narratives about why people migrate that are empirically false in that they ignore the transnational and economically and politically structured relationships that citizens and migrants already share with one another. The moral analogy of citizen 
"bystanders" who may or may not be obligated to help migrant "strangers" is therefore inaccurate and misleading, and it can even be appropriated in service to the conservative view that migrants are a threat to national security (Rajendra 2017, pp. 28-30). How and why can responsibility be assigned and assumed in light of these prior relationships, particularly if the "bystanders" are more accurately termed complicit beneficiaries of an unjust immigration system and international order?

To address such difficult questions, Rajendra argues that justice must be reframed theoretically as responsibility to relationships. This task is partly accomplished by identifying false, incomplete, or nonexistent narratives about structurally vulnerable agents, which facilitate the avoidance of responsibility for harm by structurally powerful agents, and replacing them with fuller and more accurate narratives about the relationship between these two parties as the basis for inferring responsibilities (Rajendra 2017, pp. 109, 116, 123, 128). The very nature of this task precludes the possibility of a single formula, principle, criterion, heuristic device, or even a single narrative for allocating responsibilities to agents in relation to one another, precisely because it requires sorting through the particularities of specific kinds of relationships and the narratives we tell about them. Thus, Rajendra focuses on four different types of relationships between citizens and migrants, examines the dominant narratives (or lack thereof) that shape perception in each case, and proposes an allocation of responsibilities on the basis of narratives that are more faithful to the real history of these relationships (Rajendra 2017, pp. 130-36). For example, she argues that undocumented migrants from Mexico living in the U.S. deserve full citizenship in recognition of the historical relationship between the two nations, as it has been structured by the actions of specific U.S.-based private businesses, the inaction and ignorance of U.S. consumers, and free-trade agreements such as NAFTA. In this case, the granting of citizenship, in recognition of the fact that it is deserved in the context of this particular web of relationships, would be a practice of moral accountability.

How can such a theory of justice as responsibility to relationships apply to the moral crisis of racial injustice in the U.S. context (which is inseparable from the crisis of immigration injustice)? Similar to the transnational, structural relationships shared by migrants and citizens, the unjust interracial relationships of U.S. society are not the result of nature or free choice but social construction through historical processes in which European perceptions about the meaning and significance of phenotypical differences have become institutionalized as a pattern of structured racial domination (Copeland 2009, pp. 9-18; Massingale 2010, pp. 1-42). White beneficiaries of this institutional dominance tend to avoid responsibility for the harm they cause primarily because they tell false and incomplete narratives about their relationships with persons of color, as well as virtually nonexistent narratives about their own intraracial identities as white (Townes 2006, pp. 58-69). One dominant narrative of interracial relationships imputes criminality and violence to black bodies as essentialized racial traits, which conveniently repositions white bodies as essentially innocent (Yancy 2008; Muhammad 2010). Another narrative suggests that differences in social outcomes are the result of the different cultural values of racial groups, which rests on the further assumption that U.S. society functions as a meritocracy (Bonilla-Silva 2014, pp. 73-99; Townes 1995, pp. 124-35; 2006, pp. 115-38). These narratives are not only false representations of the real history of interracial and intraracial relationships that have provided legitimation for institutional racism, they also constitute "an idolatrous 'antitheology' of white supremacy" that assists white Christians in particular who wish to avoid responsibility for structured racial harm (Jaycox 2017, p. 309).

In other words, there is widespread denial concerning the nature and history of the prior relationships shared between white persons and persons of color in the U.S. context. As was the case with Rajendra's analysis of the relationships between citizens and migrants, so too for interracial relationships: The language of well-intentioned white "bystanders" who consider their obligations to vulnerable "strangers" of color is an inappropriate analogy for approaching and repairing structured harm in racialized relationships. Moral repair for this harm cannot credibly be offered in spirit of altruism or charity by a powerful group aiming to help a vulnerable group; it is more honest and 
faithful to the history of racial injustices to say that repair is owed in and through practices of moral accountability, which include, but are not limited to, the paying of monetary reparations.

\section{Moral Accountability in Christian Ethical Perspective}

In the interest of gaining further clarity and precision, I will examine the connections and overlap between the account of moral accountability I am proposing here and related ethical concepts being developed in Christian ethics in order to discern and assign responsibility for U.S. racial injustices. Speaking from a mainline Protestant standpoint, Jennifer Harvey (2011) outlines and contrasts two broad ethical paradigms: reconciliation and reparation. The reconciliation paradigm, which emerged as a white appropriation of Martin Luther King, Jr.'s theological vision of "the beloved community," identifies segregation or racial separateness as the primary problem, which is corrected through inclusion and the embrace of diversity, minimization of the significance of racial difference, and an emphasis on shared, universal humanity (Harvey 2011, pp. 58-61; Cone 1991, pp. 121-37, 214-18). The reparation paradigm, which emerged as a black theological response to the Black Power Movement, identifies the historical and ongoing white exploitation of black communities as the primary problem, which is corrected through an acknowledgment of racial particularity, including white particularity, as well as moral repair, including the redistribution of material resources owed in justice (Harvey 2011, pp. 62-63; Cone 1997, pp. 32-33, 143-52). Indeed, authentic reconciliation remains a theological value and worthy moral goal, provided that the reform of unjust institutions and the repairing of structural harm serve as the means to restoring just relationships in society (De Gruchy 2002, pp. 199-209). Similarly to the "counterfeit reconciliation" condemned in the Kairos Document as inappropriate for the South African context, the white "reconciliation" paradigm fails because it asks white Americans to do exactly nothing, most crucially in that it excuses them from any critical examination of white identity formation, white responsibility for historical and ongoing racial harm, or white material interests and dominance (Kairos Theologians 1986; Harvey 2011, pp. 61-62). The reparations paradigm anticipates and corrects for this persistent white reluctance:

A reparations paradigm brings whiteness plainly into view because reparations necessitate an actual contending with history. Rather than a general brokenness, reparations recognize that brokenness comes from specific harms done. Addressing brokenness requires addressing that harm and naming a perpetrator. For racial justice to be pursued authentically as a community, the perpetrator or perpetrators must come forward and participate in concrete redress. (Harvey 2011, p. 64)

In the context of racial injustice in the U.S., practices of moral accountability work in service to this reparations paradigm by offering concrete routes of participation for white persons and persons of color alike in this process of determining what is owed in justice, who owes the debt, and how it is to be paid. Moral accountability, when practiced in the context of an organized grassroots collective, facilitates a dialogical encounter in which white perpetrators and guilty beneficiaries name themselves as such in front of victims and survivors, assume responsibility for harm, narrate the work they are doing and plan to do in order to repair that harm and transform the structural causes of that harm, and answer questions from persons of color. Thus, practices of moral accountability are designed to resist and disrupt the white reconciliation paradigm in which the pursuit of justice happens on the oppressor's terms.

The scope and purpose of moral accountability practices can be further clarified by reference to two other ethical concepts that are more prominent in Catholic discussions of responsibility for racial injustices: cooperation and complicity. Catholic tradition has long held that agents who indirectly "foresee" and do not directly intend the evil consequences of their actions are still responsible for those consequences to some degree. This basic presupposition of Catholic casuistry informs the principle of licit material cooperation in evil, devised in the interest of determining whether and how a well-intentioned agent may involve themselves in the wrongful action of another agent or in an unjust 
system, in order to reduce a harmful outcome (Barrera 2014, p. 14). This general principle has been applied to particular ethical questions about stem cell research, HIV/AIDS prevention, participation in electoral politics, and economic supply chains (Keenan 1989; Kaveny 2000; Rubio 2011).

However, Laurie Cassidy and Alex Mikulich call attention to the limitations of this principle in regard to racial injustices, namely in that it tends to create an "assumption of distance that allows me to estimate how much I am actually participating in what is distinct from me" (Cassidy and Mikulich 2013, p. 8). This illusory "distance" is largely a product of white socialization that frames racism as an isolated action of extraordinary evil committed by certain bigoted individuals rather than a profoundly normalized, pervasive social system of racial domination in relation to which white Americans are implicated as guilty beneficiaries (Massingale 2010, pp. 13-19). The question of whether and how the "good" white person can "cooperate" in the evil of systemic racism completely misses the point. The agents in question are already socially situated and are already responsible for harm, regardless of their intentions and choices.

Thus, Cassidy and Mikulich propose complicity as a more adequate ethical category than cooperation for white people who wish to analyze and respond to systemic racism. Complicity removes the assumption of distance and "takes as its starting point our entanglement with oppression" (Cassidy and Mikulich 2013, p. 9). Furthermore, the category of complicity reframes responsibility, replacing the question of "what the individual [white person] is required to do" with the question of "what needs to be done" in an organized collective (Cassidy and Mikulich 2013, p. 10; Applebaum 2010, pp. 119-53). Thus, complicity is not so much an alternative casuistry principle as it is a reframing of the moral realities that agents assume to be true when employing principles. Cassidy and Mikulich (2013) criticize Julie Rubio (2011) for her effort to rehabilitate the principle of cooperation, but she has responded to their critique by noting that this principle remains necessary "to make distinctions among cooperators" in the moral analysis of racial oppression, as well as to call individuals to fulfill their duty to resist the structural causes of racialized harm (Rubio 2017, pp. 113, 118).

Practices of moral accountability offer an effective way to address the questions and concerns behind this cooperation-complicity debate. The extent to which interracial and intraracial relationships are or are not structured by such practices shapes perception of moral realities more fundamentally than the language and concepts being used. One's sense of what counts as licit and illicit cooperation, whether this individual or group is or is not complicit in this social evil, or even whether such concepts are adequate and truthful representations of moral reality, depends largely on the context of community relationships in which differently racialized humans exercise responsible agency with more or less accountability to one another. Consider the way the questions and concerns are typically posed: How do we change the basic conceptual frames white people use to interpret their world and their implication in its evils? How do we motivate white people to resist and dismantle the status quo while they still benefit from it? Can we make ethical distinctions between the different degrees or levels of culpability to be assigned to differently positioned white people? Note that none of these lines of inquiry really succeed in decentering the notion that white people can unilaterally solve the problem of racism through their own agency. While Rubio $(2011,2017)$ correctly notes that the principle of cooperation has the advantage of assigning to particular individuals responsibility for resisting the social sin in which they are implicated, the bare realization of personal guilt for societal evil hardly constitutes a guarantee that white people will assume responsibility for white supremacist harm or participate in efforts of resistance. This realization is just as likely, if not more likely, to contribute to the deeper problem of privileged helplessness, apathy, and despair experienced by guilty beneficiaries who lack accountable relationships with communities already doing the work of resistance (Vasko 2015).

As a complement to the deconstructive analysis offered by Cassidy and Mikulich (2013), Margaret Pfeil $(2007,2013 a, 2013 b)$ builds on the work of Diana Hayes (1998) and Copeland $(1996,1997,2004)$ as she proposes a constructive spirituality of white resistance to systemic racism, including practices of asceticism toward material resources (presumably in order to pay reparations), dismantling structures of white privilege, engaging in public nonviolent witness, subversive memory, and lament. However, 
no white spirituality, by Pfeil's own admission, is going to dismantle a system of white supremacy in the absence of an organized community context in which resistance is practiced with proper accountability to persons of color. Considering Vincent Lloyd's observation that "when the privileged act in concert, whatever their goal, the result is to further privilege," even a well-intentioned white effort to acknowledge and renounce white privilege will simply generate more in-group, bonding social capital among white people if there is no organizational accountability to those who most acutely experience the harms of racism (Lloyd 2016, p. 178). Katie Grimes goes as far as to suggest that the ethical discourse built upon the concept of white privilege has actually become dysfunctional, in that it "overestimates the possibility and importance of white agency and self-reform" and relies upon rational persuasion to change white behavior (Grimes 2018, pp. 42-43). Clearly, there is a profound moral danger inherent in even the most well-intentioned white attempt to rectify racial harms in a unilateral, unaccountable fashion: the likely result of re-inscribing the pattern of racial domination at another level while mimicking a praxis of resistance.

\section{Moral Accountability and Payback, Revisited}

Aided by this ethical analysis of moral accountability practices in the context of U.S. racial injustice, we are now in a position to return to the distinction previously drawn between payback and accountability. Moral accountability practices, operating in the context of organized collectives, restructure relationships in order to disrupt the dominant structural pattern, thereby increasing the likelihood that complicit beneficiaries will assume responsibility for harm, as a practical precondition for the moral repair and structural reform of relationships. Payback, a specific type of punishment constituted by the belief that the suffering of perpetrators compensates for the suffering of victims and survivors, is highly limited as a means to preserving or reconstructing a moral culture of responsible agency. It is exclusively aimed at punishing those to whom responsibility for past harm is assigned, rather than assuming responsibility for the future of relationships via moral repair and structural reform, and it tends to neglect the role of complicit beneficiaries in sustaining structured patterns of harm. But despite these conceptual and practical limitations, payback also gestures toward a moral principle fundamental to rectifying unjust relationships, that any response should be proportionate to the gravity and context of the harm suffered. The specifically legal concept of accountability, operative in judicial processes for criminal and civil violations, presumes this moral principle of proportionality.

In this light, I would like to blur the distinction between payback and moral accountability slightly, so that we can afford ourselves the conceptual space to ask whether the latter includes some kind of non-coercive and extralegal, yet still recognizably punitive, element. In the context of racial injustices, I argue that moral accountability practices do include such an element, in that white people who assume responsibility as beneficiaries of racial harm typically experience a disturbing transformation of their self-perception. To assume responsibility for racial harm in the context of a white supremacist system is to confront oneself as capable of incurring guilt for non-voluntary harm, including the likely possibility of guilt for future non-voluntary harms, even while resisting the system.

In order to address the question of whether and how agents can deserve punishment, ethical theorists typically draw a distinction between incurring guilt for harms committed in the past (roughly equivalent to what I have previously called "assigning responsibility") and taking responsibility for the future of harmed relationships (roughly equivalent to what I have previously called "assuming responsibility"). Iris Marion Young maps this distinction onto different types of relational roles, arguing that "guilt should be attributed to persons who commit crimes or wrongs, or directly contribute by their actions to crimes or wrongs. Being responsible, but not guilty, is a designation that belongs to persons whose active or passive support for governments, institutions, and practices enables culprits to commit crimes and wrongs" (Young 2013, pp. 91-92). According to Young, perpetrators are guilty, while beneficiaries are responsible yet not guilty. If this distinction is applicable to the context of unjust racial relationships, then white perpetrators who directly caused past racial harms to persons of color would incur guilt, and perhaps justly deserve some degree of punishment. White beneficiaries, 
on the other hand, would engage their more indirect responsibility for racial harm by practicing moral accountability to persons of color, in the context of the political goals of grassroots anti-racism collectives, reparative state policies, and institutional reforms.

However, this theoretical distinction between guilty perpetrators and responsible beneficiaries is too clean and neat for the context of this investigation, since it relies on a concept of voluntariness that not only is descriptively inadequate to the reality of structured relationships but also leaves out the possibility that complicit beneficiaries can incur guilt. For instance, William Schweiker, who suggests that responsibility can be shared among the members of a social group, nevertheless maintains that punishment can be imposed on specific guilty agents only to the extent that wrongful actions are voluntary (Schweiker 1995, pp. 136-37, 149-52). Being troubled by the complexity of harm in structured relationships, Schweiker has more recently noted that a lack of voluntariness when causing harm can facilitate the avoidance of guilt and responsibility: "If the consequences exceed the actual power of an acting agent or collection of agents, can they be held accountable for those damages?" (Schweiker 2009, p. 487). However, he does not answer his own question, instead asserting that a future-oriented norm "to respect and enhance the integrity of life" can inspire a commitment to responsible action (Schweiker 2009, p. 494).

Wonchul Shin and Elizabeth Bounds have also recently argued that structured harm, being "an unintended consequence of the combination of actions and interactions of a large number of individual or institutional actors following socially accepted ideas and rules that constrain or direct action," should be approached not with backward-looking notions of "personal responsibility" but with a future-oriented model of "shared responsibility for moral repair ... grounded in restorative justice" (Shin and Bounds 2017, p. 156). However, the restorative justice framework they propose, which they explicate by reference to the Parable of the Good Samaritan, is not capable of handling the difficult problem of assigning responsibility for specific types of structured harm to particular agents and groups of agents-indeed, it aims to avoid doing so, since no one intended the harm. Instead, they explicitly claim that "all are responsible to aid the person lying in the road" (Shin and Bounds 2017, p. 164). Overall, the practical weakness of the solutions proposed by Schweiker, Shin, and Bounds is that they, having correctly perceived that structured harms lack voluntariness, respond by diffusing responsibility for these harms among such a wide number of agents that no one is likely to assume it, because there are no consequences for not doing so.

Moreover, relying on voluntariness as the central criterion for assigning responsibility, imputing guilt, and determining the appropriateness of any punishment is simply not commensurate with an adequate moral description of structural emergence. Ethicists must grapple with the fact that the institutions and cultures that mediate human relationships have emergent properties, the social effects of which are not reducible to the sum of the agency of all individuals in these relationships (Traina 2014; Finn 2014, 2016). It is therefore plausible to say that agents can cause, and in some sense can be responsible for, non-voluntary harm via their participation in institutionally and culturally structured relationships, even and especially if that harm could not have been committed or prevented through their conscious, deliberate choices. Given that voluntariness is no longer a sufficient criterion for addressing moral questions about responsibility in a structural context, we need to consider other additional criteria.

The tasks of assigning and assuming responsibility encounter an even more troubling challenge than structural emergence when ethicists confront the reality of malformed moral consciences. Bryan Massingale notes that unconscious socialization into the culture of white supremacy severely limits responsible agency, in that "one's sense of right and wrong, one's grasp of morality, and one's very conscience become blunted and twisted ... This is not merely a matter of culpable ignorance. Nor do I believe that the issue can be satisfactorily resolved by an appeal to what the tradition calls invincible ignorance" (Massingale 2015, p. 64). In other words, it is nearly impossible to persuade an agent whose moral conscience has been malformed by racism that they must assume responsibility for the non-voluntary racial harm they cause by participating in a racist system. Such an agent will likely 
understand racial harm to be a completely normal, inevitable, necessary, or even good aspect of social existence; thus, the imperative to assume responsibility is rendered unintelligible. In such a social and cultural context, most white people will also be less able to accurately assign responsibility for racial harm, because they do not even recognize it to be a moral violation in the first place and are more likely to perceive themselves as the real "victims."

Moreover, if we consider the normative problem of malformed consciences in conjunction with the descriptive reality of structural emergence, our previous distinction between direct perpetrators and indirect beneficiaries becomes less ethically significant. It may be that membership in one group or the other is determined somewhat arbitrarily by the particular institutional role one happens to occupy in the system that facilitates structured racial harm, rather than by any significant differences in intentionality, knowledge, or character virtue between the two groups. However, the exercise of agency is not entirely structurally determined, because even perpetrators and beneficiaries do retain freedom; otherwise, it would be meaningless to hold them responsible for harm. In this light, the more ethically significant distinction between social groups is that of political allies and political adversaries in the struggle for racial justice. Membership in one group or the other is determined by one's free and responsible decision to participate or not to participate in collective action to resist the structural causes of racial harm and repair harmed relationships.

However, as previously suggested, the free decision of perpetrators and beneficiaries to participate in an organized anti-racism collective as allies, to practice moral accountability, and thus to assume responsibility for structured racial harm, comes at a cost. This cost can be described as a disturbing transformation of self-perception, in which those making this decision necessarily must also confront themselves as capable of incurring guilt for non-voluntary harm, including the likely possibility of guilt for future non-voluntary harms, even while resisting the current system. As Cristina Traina notes, "even to fight against structural evil is to participate in it, to attempt to dismantle and rebuild the machine while it is still running in overdrive, while one is being either starved by its injustices or overfed by them. Not surprisingly, the consequence of any serious effort to dismantle it is often to be crushed by it" (Traina 2017, p. 5). This reality of structural evil, which has been named in Christian traditions as "original sin," must be named in the U.S. political context as the system of white supremacy. This system is the "cosmic tyrant" that constrains the free exercise of responsible agency in our relationships (Croasmun 2017). Agents feed it and are fed by it, and its resulting emergent properties continue to draw agents into the process of distributing and compounding non-voluntary and involuntary racial harms, even as they voluntarily and collectively resist it.

In this context of objectified structural evil, white perpetrators and beneficiaries who resist in accountability to persons of color experience a certain kind of punishment. It is not a legal punishment; there is no judge or jury to mete it out. It is not exactly "payback" either; it is not imposed externally in order to reduce or compensate for anyone else's suffering. Rather, the punishment is the psychological and moral conflict prompted by the realization that one inescapably participates and remains implicated in the structural evil of white supremacy even while aiming to dismantle it. This struggle is analogous to Paul's own interior conflict: "I do not understand my own actions. For I do not do what I want, but I do the very thing I hate" (Rom. 7:15). Paul's way of addressing this interior conflict was not individualistic, however, since his aim was to organize a social movement upon the free gift of grace offered in Jesus Christ, working within the structural evil of the Roman Empire in order to subvert its power from within. The punishment he experienced was simply part of the discipline required for a privileged person to participate in the accountable (though imperfect) communities of the early church, which were characterized, among other things, by the practice of redistributing material resources in defiance of patriarchal household norms and the extractive, exploitative incentives embedded in the imperial economic order.

If we extend Paul's discipline by analogy to the current contextual manifestation of structural evil, then being a white ally who practices accountability to persons of color in an organized, anti-racism collective will inevitably involve this peculiar punishment, this realization that one is not in control of 
one's ability to avoid causing harm due to the emergent properties of the structural evil from which one benefits. This peculiar punishment suggests that a certain amount of white agency will be inescapably dysfunctional from a normative standpoint; it may even be practically useless in some situations, depending on what the short-term political goals of the collective happen to be. As was the case with Paul, any effort to discern what kind of disciplined response is appropriate for those who experience this disturbing transformation of self-perception must look to what is possible in the relationships that constitute the anti-racism collective, not dwelling on the question of what the individual white person must do. The collective alone, carefully organized by accountable practices but remaining imperfect, can begin to mediate the repair of harmed interracial and intraracial relationships, the restructuring of these relationships in order to facilitate responsible agency, the gradual extension of this model into the broader society to build solidarity at the grassroots level, and ultimately the incorporation of all into the new moral culture that is already emerging.

\section{Conclusions}

In this essay, I have developed a conceptual framework for practices of moral accountability by drawing upon Rajendra's reframing of political justice as responsibility to unchosen relationships. Thus understood, moral accountability practices offer an alternative to both payback and forgiveness for members of post-conflict societies who wish to reconstruct, and for members of increasingly authoritarian societies who wish to preserve, a moral culture. Moral accountability practices operative at the grassroots level of society create new cultural conditions that make more likely the voluntary assumption of responsibility for structured harm by the perpetrators and guilty beneficiaries to whom such responsibility is assigned. Having given particular consideration to the U.S. political context of structured racial harm, I highlighted several examples of moral accountability being practiced locally by the members of anti-racism collectives in Seattle, including strategic roles during public witness, racial identity caucusing in classroom environments, and counter-framing in exclusively white networks. Such practices offer an effective way to restructure unjust interracial and intraracial relationships and reallocate responsibilities in light of a more honest and faithful narrative of these relationships.

This framework for understanding moral accountability overlaps significantly with other major concepts being developed in Christian ethics for the purpose of addressing racial injustices, particularly reparation and complicity. However, attentiveness to accountability underscores the fact that any white response to the realization of complicity or the imperative to repair harm must be practiced in the context of an anti-racism collective structured by appropriate interracial accountability to persons of color. An understanding of the moral danger of exercising white agency unilaterally, even and especially when well-intentioned, can be deepened further by considering the dysfunctional operation of white agency in a context of structurally emergent white supremacy and malformed moral consciences. However, the accountable organizational pattern that structured Paul's work in the early church provides an analogy that can direct the reincorporation of individually dysfunctional white agents into the collective work of anti-racism organizing, including the eventual dismantling of the dominant institutional and cultural pattern of structured racial harm.

Funding: This research received no external funding.

Acknowledgments: The author wishes to acknowledge Tisha Rajendra, Katie Grimes, and the anonymous reviewers, whose helpful and constructive suggestions greatly improved the quality of this essay.

Conflicts of Interest: The author declares no conflict of interest.

\section{References}

Ahmed, Sara. 2007. A Phenomenology of Whiteness. Feminist Theory 8: 149-68. [CrossRef]

Applebaum, Barbara. 2010. Being White, Being Good: White Complicity, White Moral Responsibility, and Social Justice Pedagogy. Lanham: Lexington Books.

Barrera, Albino. 2014. Market Complicity and Christian Ethics. New York: Cambridge University Press. 
Bonilla-Silva, Eduardo. 2014. Racism without Racists: Color-Blind Racism and the Persistence of Racial Inequality in America, 4th ed. Lanham: Rowman \& Littlefield.

Calhoun, Cheshire. 1992. Changing One's Heart. Ethics 103: 76-96. [CrossRef]

Cassidy, Laurie M., and Alex Mikulich. 2013. Introduction: The Invisibility of White Complicity in Hyper-Incarceration. In The Scandal of White Complicity in US Hyper-Incarceration: A Nonviolent Spirituality of White Resistance. Edited by Alex Mikulich, Laurie M. Cassidy and Margaret R. Pfeil. New York: Palgrave Macmillan, pp. 1-28.

Chapman, Audrey R. 2008. Perspectives on the Role of Forgiveness in the Human Rights Violations Hearings. In Truth and Reconciliation in South Africa: Did the TRC Deliver? Edited by Audrey R. Chapman and Hugo van der Merwe. Philadelphia: University of Pennsylvania Press, pp. 66-89.

Cone, James H. 1991. Malcolm \& Martin E America: A Dream or a Nightmare. Maryknoll: Orbis Books.

Cone, James H. 1997. Black Theology and Black Power. Maryknoll: Orbis Books.

Copeland, M. Shawn. 1996. The Exercise of Black Theology in the United States. Journal of Hispanic/Latino Theology 3: 5-15.

Copeland, M. Shawn. 1997. Foundations for Catholic Theology in an African American Context. In Black and Catholic: The Challenge and Gift of Black Folk. Edited by Jamie T. Phelps. Milwaukee: Marquette University Press, pp. 107-47.

Copeland, M. Shawn. 2004. Political Theology as Interruptive. CTSA Proceedings 59: 71-82.

Copeland, M. Shawn. 2009. Enfleshing Freedom: Body, Race, and Being. Minneapolis: Fortress Press.

Croasmun, Matthew. 2017. The Emergence of Sin: The Cosmic Tyrant in Romans. New York: Oxford University Press.

Crossroads Antiracism Organizing \& Training. 2008. Racial Identity Caucusing: A Strategy for Building Anti-Racist Collectives. Available online: http://www.crossroadsantiracism.org/wp-content/themes/crossroads/PDFs/ Racial\%20Identiy\%20Caucusing\%20Strategy.pdf (accessed on 7 June 2019).

De Gruchy, John W. 2002. Reconciliation: Restoring Justice. Minneapolis: Fortress Press.

Feagin, Joe R. 2010. The White Racial Frame: Centuries of Racial Framing and Counter-Framing. New York: Routledge. Finn, Daniel K. 2014. Social Causality and Market Complicity: Specifying the Causal Roles of Persons and Structures. In Distant Markets, Distant Harms: Economic Complicity and Christian Ethics. Edited by Daniel K. Finn. New York: Oxford University Press, pp. 243-60.

Finn, Daniel K. 2016. What Is a Sinful Social Structure? Theological Studies 77: 136-64. [CrossRef]

Grimes, Katie Walker. 2018. Black Exceptionalism: Anti-Blackness Supremacy in the Afterlife of Slavery. In Anti-Blackness and Christian Ethics. Edited by Vincent W. Lloyd and Andrew Prevot. Maryknoll: Orbis Books, pp. 41-60.

Gutiérrez, Gustavo. 2008. Poverty, Migration, and the Option for the Poor. In A Promised Land, a Perilous Journey: Theological Perspectives on Migration. Edited by Daniel G. Groody and Gioacchino Campese. Notre Dame: University of Notre Dame Press, pp. 76-86.

Hartman, Geoffrey H., ed. 1994. Introduction: Darkness Visible. In Holocaust Remembrance: The Shapes of Memory. Cambridge: Blackwell, pp. 1-22.

Harvey, Jennifer. 2011. Which Way to Justice? Reconciliation, Reparations, and the Problem of Whiteness in US Protestantism. Journal of the Society of Christian Ethics 31: 57-77. [CrossRef]

Hayes, Diana L. 1998. And When We Speak: To Be Black, Catholic, and Womanist. In Taking Down Our Harps: Black Catholics in the United States. Edited by Diana L. Hayes and Cyprian Davis. Maryknoll: Orbis Books, pp. 102-19.

Hoffmann, Deborah, and Frances Reid. 2000. Long Night's Journey into Day: South Africa's Search for Truth and Reconciliation. San Francisco: California Newsreel, DVD.

Hollenbach, David. 2008. Internally Displaced People, Sovereignty, and the Responsibility to Protect. In Refugee Rights: Ethics, Advocacy, and Africa. Edited by David Hollenbach. Washington: Georgetown University Press, pp. 177-93.

Jaycox, Michael P. 2017. Black Lives Matter and Catholic Whiteness: A Tale of Two Performances. Horizons 44: 306-41. [CrossRef]

Kairos Theologians. 1986. The Kairos Document: Challenge to the Church: A Theological Comment on the Political Crisis in South Africa, 2nd ed. Grand Rapids: Eerdmans.

Kaveny, M. Cathleen. 2000. Appropriation of Evil: Cooperation's Mirror Image. Theological Studies 61: 280-313. [CrossRef] 
Keenan, James F. 1989. Prophylactics, Toleration, and Cooperation: Contemporary Problems and Traditional Principles. International Philosophical Quarterly 29: 205-20. [CrossRef]

Lloyd, Vincent W. 2016. For What Are Whites to Hope? Political Theology 17: 168-81. [CrossRef]

Massingale, Bryan N. 2010. Racial Justice and the Catholic Church. Maryknoll: Orbis Books.

Massingale, Bryan N. 2015. Conscience Formation and the Challenge of Unconscious Racial Bias. In Conscience and Catholicism: Rights, Responsibilities, and Institutional Responses. Edited by David E. DeCosse and Kristin E. Heyer. Maryknoll: Orbis Books, pp. 53-68.

Mingo, AnneMarie. 2018. Just Laws, Unjust Laws, and Theo-Moral Responsibility in Traditional and Contemporary Civil Rights Activism. Journal of Religious Ethics 46: 683-717. [CrossRef]

Minow, Martha. 1998. Between Vengeance and Forgiveness: Facing History after Genocide and Mass Violence. Boston: Beacon Press.

Muhammad, Khalil Gibran. 2010. The Condemnation of Blackness: Race, Crime, and the Making of Modern Urban America. Cambridge: Harvard University Press.

Niebuhr, H. Richard. 1999. The Responsible Self: An Essay in Christian Moral Philosophy, rev. ed. Louisville: Westminster John Knox Press.

Nishi, Naomi W., Cheryl E. Matias, Roberto Montoya, and Geneva L. Sarcedo. 2016. Whiteness FAQ: Responses and Tools for Confronting College Classroom Questions. Journal of Critical Thought and Praxis 5: 1-34. [CrossRef]

Nussbaum, Martha C. 2016. Anger and Forgiveness: Resentment, Generosity, Justice. New York: Oxford University Press.

O'Connell, Maureen H. 2014. After White Supremacy? The Viability of Virtue Ethics for Racial Justice. Journal of Moral Theology 3: 83-104.

O'Neill, William. 2002. Imagining Otherwise: The Ethics of Social Reconciliation. Journal of the Society of Christian Ethics 22: 183-99. [CrossRef]

O'Neill, William. 2009. Christian Hospitality and Solidarity with the Stranger. In And You Welcomed Me: Migration and Catholic Social Teaching. Edited by Donald Kerwin and Jill Marie Gerschutz. Lanham: Lexington Books, pp. 149-55.

Pfeil, Margaret R. 2007. The Transformative Power of the Periphery: Can a White U.S. Catholic Opt for the Poor? In Interrupting White Privilege: Catholic Theologians Break the Silence. Edited by Laurie M. Cassidy and Alex Mikulich. Maryknoll: Orbis Books, pp. 127-46.

Pfeil, Margaret. 2013a. A Spirituality of Nonviolent White Resistance to the Reality of Hyper-Incarceration. In The Scandal of White Complicity in US Hyper-Incarceration: A Nonviolent Spirituality of White Resistance. Edited by Alex Mikulich, Laurie M. Cassidy and Margaret R. Pfeil. New York: Palgrave Macmillan, pp. 143-65.

Pfeil, Margaret. 2013b. Contemplative Action: Toward White Nonviolent Resistance to Hyper-Incarceration. In The Scandal of White Complicity in US Hyper-Incarceration: A Nonviolent Spirituality of White Resistance. Edited by Alex Mikulich, Laurie M. Cassidy and Margaret R. Pfeil. New York: Palgrave Macmillan, pp. 167-85.

Philpott, Daniel. 2012. Just and Unjust Peace: An Ethic of Political Reconciliation. New York: Oxford University Press.

Picca, Leslie Houts, and Joe R. Feagin. 2007. Two-Faced Racism: Whites in the Backstage and Frontstage. New York: Routledge.

Rajendra, Tisha M. 2017. Migrants and Citizens: Justice and Responsibility in the Ethics of Immigration. Grand Rapids: Eerdmans Publishing.

Rubio, Julie Hanlon. 2011. Moral Cooperation with Evil and Social Ethics. Journal of the Society of Christian Ethics 31: 103-22. [CrossRef]

Rubio, Julie Hanlon. 2017. Cooperation with Evil Reconsidered: The Moral Duty of Resistance. Theological Studies 78: 96-120. [CrossRef]

Scheid, Anna Floerke, and Elisabeth T. Vasko. 2014. Teaching Race: Pedagogical Challenges in Predominantly White Undergraduate Theology Classrooms. Teaching Theology E Religion 17: 27-45.

Schweiker, William. 1995. Responsibility and Christian Ethics. New York: Cambridge University Press.

Schweiker, William. 2009. Responsibility and Moral Realities. Studies in Christian Ethics 22: 472-95. [CrossRef]

Shin, Wonchul, and Elizabeth M. Bounds. 2017. Treating Moral Harm as Social Harm: Toward a Restorative Ethics of Christian Responsibility. Journal of the Society of Christian Ethics 37: 153-69. [CrossRef]

Shriver, Donald W., Jr. 1997. An Ethic for Enemies: Forgiveness in Politics. New York: Oxford University Press.

Townes, Emilie M. 1995. In a Blaze of Glory: Womanist Spirituality as Social Witness. Nashville: Abingdon Press. 
Townes, Emilie M. 2006. Womanist Ethics and the Cultural Production of Evil. New York: Palgrave Macmillan.

Tracy, David. 1991. The Analogical Imagination: Christian Theology and the Culture of Pluralism. New York: Crossroad Publishing.

Traina, Cristina L. H. 2014. Facing Forward: Feminist Analysis of Care and Agency on a Global Scale. In Distant Markets, Distant Harms: Economic Complicity and Christian Ethics. Edited by Daniel K. Finn. New York: Oxford University Press, pp. 173-201.

Traina, Cristina L. H. 2017. This Is the Year: Narratives of Structural Evil. Journal of the Society of Christian Ethics 37: 3-19. [CrossRef]

Tutu, Desmond. 2000. No Future without Forgiveness. New York: Image Books.

Vasko, Elisabeth T. 2015. Beyond Apathy: A Theology for Bystanders. Minneapolis: Fortress Press.

Wilson, Richard A. 2001. The Politics of Truth and Reconciliation in South Africa: Legitimizing the Post-Apartheid State. New York: Cambridge University Press.

Yancy, George. 2008. Black Bodies, White Gazes: The Continuing Significance of Race. Lanham: Rowman \& Littlefield. Young, Iris Marion. 2013. Responsibility for Justice. New York: Oxford University Press.

(C) 2019 by the author. Licensee MDPI, Basel, Switzerland. This article is an open access article distributed under the terms and conditions of the Creative Commons Attribution (CC BY) license (http://creativecommons.org/licenses/by/4.0/). 